\section{Nowa humanistyka w Polsce: kilka bardzo subiektywnych obserwacji, koniektur, refutacji}

Ryszard Nycz
Tekst powstał w ramach realizacji projektu Innowacyjna humanistyka polonistyczna: ,tekstjako laboratorium"Narodowego Centrum Nauki, nr UMO$-2012 / 07 / B / H S 2 / 01451$.
TEKSTY DRUGIE 2017, NR 1, S. 18-40

DOI: 10.18318/td.2017.1.2

1.

Jeśli wziąć pod uwagę fakt, że idee i praktyki „nowohumanistyczne" obecne są w polskim środowisku naukowym zaledwie od niespełna 10 lat, to skala i temperatura dyskusji im towarzyszących mogą tylko cieszyć, świadcząc chyba o tym, że chodzi o sprawy - dla humanistów, dla nauk humanistycznych, dla statusu tej dziedziny wiedzy - aktualne i podstawowe. W tym krótkim, wprowadzającym szkicu chciałbym najpierw zatrzymać się na naturze (i nieporozumieniach) najważniejszych sporów, obaw czy zastrzeżeń, by potem przejść do zarysowania głównych zakresów pomału stabilizującego się pola badań nowohumanistycznych i zakończyć uwagami „z własnego podwórka" o stosunkowo wąskim nurcie tych badań, którym sam próbuję się zajmować.

Wysoka temperatura sporów jest na pewno po części efektem nakładania się na nie debat nad tzw. kryzysem humanistyki, który na Zachodzie ma już ponad czterdziestoletnią historię, a do Polski dotarł mniej więcej w tym samym czasie. Świadczy to swoją drogą o tym, że nie da się już tych kwestii rozważać jedynie w zamkniętym,
Ryszard Nycz - prof. dr hab., kierownik Katedry Antropologii Literatury i Badań Kulturowych U), pracownik IBL PAN. Redaktor naczelny "Tekstów Drugich". Członek rzeczywisty PAN i członek korespondent PAU, KNoL PAN i KNoK PAN. Przewodniczący Komitetu Redakcyjnego serii „Nowa Humanistyka". Ostatnio opublikował: Poetyka doświadczenia. Teoria - nowoczesność literatura (2012). Kontakt: ryszard. nycz@uj.edu.pl. 
odizolowanym „od świata” kręgu profesjonalistów - ponieważ, krótko rzecz ujmując, wszystkie takie dyscyplinowe ścianki (między jej wnętrzem a zewnętrzem) zmurszały lub zostały poprzebijane i musimy mieć świadomość, że teraz wszyscy jesteśmy w tym samym „wnętrzu”, a to znaczy, że zarazem i na widoku publicznym.

W sprawie owego "kryzysu” chciałbym tu napisać jedynie, co następuje. Po pierwsze, ma on swe rzeczywiste podstawy w transformacji technologiczno-cywilizacyjnej, społecznej, kulturowej, historyczno-politycznej współczesnego świata. Humanistyczne modele badania i kształcenia zawsze zresztą reagowały na (a czasem i stymulowały) tego rodzaju przemiany - nie ma więc powodu, by tym razem było inaczej. Po drugie wszakże, wynika on, jak sądzę, także z zaskakująco skutecznej retoryki polityków i administratorów zarządzania „zasobami ludzkimi”, która nieodparcie mi przypomina efekty (przejściowe, jak wiemy, co prawda) perswazyjnej argumentacji głównego bohatera niedawnego filmu o LEGO Batmanie, któremu udało się wpędzić Jockera w ciężką depresję, gdy ten mu uwierzył, że jest nic niewart, ponieważ nigdy nie był i nie będzie kimś Ważnym, czyli Głównym Przeciwnikiem pozytywnego bohatera tej opowieści.

Humanistom, trochę podobnie, udało się wmówić, że są nic niewartymi darmozjadami (ciężko wypracowanego dorobku Podatników), a to, co robią, jest nieważne (dla Nauki) i nieprzydatne (Społeczeństwu). Jeśli wziąć pod uwagę, że podstawowa funkcja humanistyki w dalszym ciągu polega na formowaniu krytycznej samowiedzy oraz wrażliwości i sprawczej kreatywności jednostek i wspólnot, to wygląda na to, że wpędzenie humanistów w tę depresyjną pozycję jest bardzo wygodne politycznie, ponieważ pozwala instrumentalnie przejąć ich narzędzia i pola działania, zarazem obciążając ich odpowiedzialnością za mentalne i społeczne skutki tych działań (pisał o tym niedawno trafnie m.in. Marcus Miessen w Koszmarze partycypacji').

\section{2.}

Jestem przekonany, że humanistyka (także polska) ma się naprawdę nieźle, a kryzys - w sensie krytycznego fermentu, który ją teraz cechuje jest świadectwem przede wszystkim dynamicznego rozwoju i przemian. Kierowane w jej stronę ostrza krytyki mają, co znamienne, charakter

1 M. Miessen Koszmar partycypacji, przeł. M. Choptiany, Fundacja Nowej Kultury Bęc Zmiana, Warszawa 2013. 
antynomiczny, a zawęźlają się teraz, jak sądzę, wokół trzech kwestii spornych: społecznej przydatności, nowatorskiej rangi merytorycznej i dyscyplinowego profesjonalizmu.

Kwestia pierwsza: społecznej przydatności. Jedni głoszą, że humanistyka powinna podejmować i rozwiązywać przede wszystkim problemy społecznie i cywilizacyjnie istotne współcześnie, zamiast zamykać się w wieży z kości słoniowej swych anachronicznych, hermetycznych zagadnień. Taki jest chyba sens osławionej uwagi brytyjskiego ministra o brytyjskich mediewistach (a mediewiści, jak wiadomo, są uznawani - także w Polsce - za kompetencyjną elitę humanistyki), który powiedział, że nie ma nic „przeciwko temu, aby dla celów ozdobnych istniało kilku mediewistów, ale państwo nie ma powodu, żeby za nich płacić" ${ }^{2}$. Drudzy natomiast argumentują, że odejście humanistyki od misji polegającej na obronie autonomii i prowadzeniu profesjonalnie poprawnych, neutralnych i obiektywnych badań jest przejawem ideologicznej degeneracji tej dziedziny wiedzy. Problemem jest wytłumaczenie jednym, że te pozornie niepotrzebne badania mają nie tylko poznawcze, ale również społeczne, bywa, że formacyjne skutki oraz znaczenie nierzadko stymulujące nowe kierunki refleksji. Problemem jest też przekonanie drugich, że żaden rodzaj autonomicznego izolacjonizmu dziś nie jest możliwy (a faktycznie nie było go i dawniej).

Kwestia druga: merytorycznej rangi narodowej humanistyki. Zdaniem jednych, żeby ją uzyskać, trzeba porzucić poczucie naukowej niższości, wynikające już z samego faktu uczenia się od obcych a mądrzejszych, a zatem, jak to jest interpretowane: imitowania zachodnich wzorów - i wglądnąć w siebie, tzn. sięgnąć do rdzennej narodowej myśli i tradycji, ponieważ tylko dzięki temu będzie możliwe wybicie się na prawdziwą oryginalność. Zdaniem drugich jedynym powszechnie uznanym miernikiem wartości jest międzynarodowa pozycja narodowej humanistyki, więc trzeba jak najszybciej wejść na tę drogę umiędzynarodowienia. Pierwsi powołują się często na śmiały koncept Alexandra Kiosseva, którego zdaniem marginalna, prowincjonalna pozycja Europy Środkowo-Wschodniej jest efektem jej samoskolonizowania, tzn. uznania własnej niższości i gorszości ${ }^{3}$. Niezależnie od inspiratorskich

2 Opinię brytyjskiego ministra edukacji Charlesa Clarke'a z 2003 roku cytuję za P. Saukko Metodologie dla studiów kulturowych. Podejście integrujące, w: Metody badań jakościowych, ed. by N.K. Denzin, Y.S. Lincoln, red. nauk. wyd. pol. K. Podemski, PWN, Warszawa 2010, t. 1, s. 499.

3 Zob. A. Kiossev Notes on Self-Colonializng Cultures, w: After the Wall. Art and Culture in Post-Communist Europe, ed. by D. Elliott, B. Pejić, Moderna Museet, Stockholm 1999. Zob. też 
walorów tej tezy, pozwalającej na zidentyfikowanie i ciekawe zinterpretowanie syndromu cech i przyczyn tego stanu rzeczy, pobrzmiewa ona dla mnie - chyba niezamierzonym? - zaskakującym resentymentalnym pogłosem rasowych tez o niższości (tu: genetycznie i etymologicznie niewolniczej) Słowian i może prowadzić do aktywacji obskuranckiej ksenofobii oraz kultu rodzimej „oryginalności” w sensie dziwacznej samoswojości (tj. w takim, w jakim mówimy czasem o kimś eufemistycznie, że jest „oryginałem”).

Skądinąd jakoś nie widać np., by istniała rdzenna poetyka piastowska bądź zostały odkryte jagiellońskie studia kulturowe (które przez jakiś rodzaj zawstydzenia własną młodszością kulturową mielibyśmy zatajać)... Generalnie rzecz biorąc, nie da się chyba zaprzeczyć, że to, co najbardziej oryginalne w historii, zawdzięczaliśmy (tak jak i inni) raczej efektom międzynarodowej wymiany i fuzji (osób i idei), zwłaszcza zaś - w naszym przypadku - oddziaływaniu niemieckiej humanistyki XIX wieku... Co nie oznacza, że jakkolwiek idee nie mają narodowości, to historycy tych idei również ich nie mają, całkiem przeciwnie, co widać po podręcznikach czy syntezach: pisane przez Anglosasów podręczniki np. do teorii literatury są zdominowane przez tradycje anglosaskie, przez Francuzów - francuskie, Niemców - niemieckie, Rosjan - rosyjskie, Czechów - czeskie... Nie widać powodów, byśmy w pisanych przez Polaków podręcznikach mieli marginalizować czy pomijać polskie oryginalne osiągnięcia.

Drudzy, jak wiadomo, nawołują do „umiędzynarodowienia”, co w praktyce sprowadza się do nacisku na anglojęzyczne publikacje wyników badań. Nie zważają przy tym na to, że najbardziej nawet profesjonalne siły i środki rzucone na uruchomienie anglojęzycznych (prawdziwie, nie anglopodobnych) czasopism, powiedzmy, Uniwersytetu Posthumanistycznego w Lęborku czy serii wydawniczej Wyższej Szkoły Krajobrazu w Ojcowie nie doprowadzą bynajmniej (w najmniejszym nawet stopniu) do automatycznego podniesienia się h-indeksu publikacji ich pracowników w światowym obiegu...

Tych pierwszych trzeba by przekonać, że odmowa konfrontacji ze światem grozi popadnięciem w nieświadomą wtórność albo głupotę czy nawet idiotyzm (w etymologicznym znaczeniu: niewykształcenia, skupienia na sobie i własnej prywatności, niezainteresowania sprawami publicznymi). Tym drugim natomiast warto próbować uprzytomnić, że wejście w nader

polskie komentarze, m.in. J. Sowy Fantomowe ciało króla, Universitas, Kraków 2011; E. Klekot, Samofolkloryzacja. Współczesna sztuka ludowa z perspektywy krytyki postkolonialnej, „Kultura Współczesna" 2016 nr 5. 
elitarny obieg światowej widzialności, uwagi, a może nawet lektury czy dyskusji, jest procesem zwykle stopniowym i żmudnym oraz obarczonym przypadkowością czy ryzykiem, a przede wszystkim koniecznością poddania się prawom (na ogół niepisanym), dyktowanym przez „fabryki” wiedzy i teorii wielkich centrów zglobalizowanej nauki (sporo mówi o tym teoria zależności centro-peryferyjnych zaadaptowana do nauk społecznych i pochodnie humanistycznych) ${ }^{4}$.

Kwestia trzecia: dyscyplinowego profesjonalizmu. Najbardziej chyba kłopotliwa, gdyż to w niej kryją się, jak sądzę, rzeczywiste a nierozwiązane problemy. Dla jednych nowość nowej humanistyki jest zwykłą uzurpacją. Jak lubił powtarzać Henryk Markiewicz, nowe to zwykle dawno zapomniane stare; zatem przed wszelką próbą użycia tego przymiotnika trzeba najstaranniej przeszukać dostępne zasoby wiedzy, by sprawdzić, czy nic podobnego tam nie powiedziano... A rezultat tej pracy z reguły oczywiście (już choćby dlatego, że każda rzecz do każdej innej może być podobna pod jakimś względem) jest lub może okazać się pozytywny. Dla innych programy nowej humanistyki to rzeczywiste zagrożenie dla zachowania owego profesjonalizmu: negują one bowiem stabilność i określoność przedmiotu badania, odrębność i jedność metody oraz w ogóle możliwość zbudowania teorii w nowoczesnym rozumieniu naukowej humanistyki - czyli jako usystematyzowanego zespołu ogólnych twierdzeń, wieńczących ostatecznie proces opracowania kompleksu orzeczeń szczegółowych.

Tym pierwszym trzeba by powiedzieć, po pierwsze, że nie było i nie ma nic bardziej historycznie relatywnego niż nowość, więc każde użycie takiego określenia ma sens jedynie w określonym kontekście. A po drugie, że cechą (a może i wyznacznikiem) intelektualno-kulturowej zmiany jest też rekonfiguracja humanistycznego dziedzictwa: podobnie jak (co dostrzegł Borges) nowy, oryginalny pisarz stwarza swoich prekursorów, tak też nowe tendencje w humanistyce pozwalają ex post dostrzec "protogeniczne”, antycypacyjne czy prekursorskie cechy w tendencjach uznanych za historycznie zamknięte czy przebrzmiałe... i ten retroaktywny mechanizm rehierarchizacji i reinterpretacji jest stałą właściwością procesu historycznych przemian myśli humanistycznej.

Tym drugim natomiast wypada przyznać, że istotnie; sporo jest do zrobienia. Poprzebijanie murów między dyscyplinami oraz między humanistyką a jej środowiskiem doprowadziło do radykalnego poszerzenia pola

4 Zob. T. Zarycki Peryferie. Nowe ujęcia zależności centro-peryferyjnych, Scholar, Warszawa 2009. 
empirycznego oraz do zastąpienia skończonej całościowej teorii jako wytworu systemowej pracy intelektualnej - rodzajem roboczego programu dopiero inicjowanego procesu badawczego, a więc także jej lokalnym, konkretnym „praktykowaniem” (wyprowadzaniem z praktycznym casusów) czy eksperymentalnymi koncepcjami badań5; a nadto do konstytuowania się przedmiotu w procesie badawczym oraz eklektyczności czy hybrydyczności metod... Wszystko to nie sprzyja, rzecz jasna, zagwarantowaniu tożsamości (post)dyscypliny? obszaru? nowohumanistycznych badań. Z czego jednak nie wynika, w moim przekonaniu, że trzeba je zawiesić do czasu, nim się ten przedmiot świeży - tzn. teoria, obiekt i metoda - jak figa ucukruje, jak tytuń uleży...

\section{3.}

Zakresy nowohumanistycznych badań nie są bynajmniej w pełni ustalone ani podzielane - tyleż na świecie, co i w Polsce. Trwają tu dalej w najlepsze merytoryczne i kompetencyjne spory, przemieszczenia metod i problematyk, negocjowania inter- i transdyscyplinarnych współdziałań. Nurt bodaj najsilniejszy, bo też najłatwiejszy do instytucjonalnego uprawomocnienia, tworzy humanistyka cyfrowa (ze względu na potężne nowe media i narzędzia) z jej LAB-ami (laboratoriami cyfrowych badań humanistycznych), rosnącymi na świecie jak grzyby po deszczu (a u nas rzadziej, ale z tendencją zwyżkową). Drugi nurt, również silny i wcześnie wykrystalizowany, tworzy humanistyka zaangażowana (w sprawy społeczne, polityczne, ekonomiczne, kulturowe...), o charakterze krytyczno-emancypacyjnym wobec nowoczesnych założeń neutralności i autonomii. Trzeci nurt zdaje się łączyć różne humanistyczne programy zakładające wykorzystanie wyników i metod, współpracę, a najlepiej także wymianę z przyrodoznawstwem i naukami ścisłymi. Nurt ten często przyjmuje nazwę humanistyki kognitywnej (ze względu na znaczenie nauk o poznaniu w tych humanistycznych poszukiwaniach). Do tej krótkiej listy trzech tendencji chciałbym dorzucić jeszcze dwie, które współcześnie rosną w siłę. Byłaby to posthumanistyka, jeśli rozumieć ją dość szeroko jako orientację badającą relacje człowieka ze środowiskiem (naturalno-kulturowym), które na niego działa i na które on oddziałuje. Ostatnim zaś, czołowym nurtem byłaby natomiast humanistyka artystyczna (jeśli tak niezdarnie można się wyrazić), mieszcząca tyleż humanistykę wykorzystującą

5 Pisałem o tym wcześniej przy różnych okazjach zob. m.in. w: R. Nycz Poetyka doświadczenia. Teoria - nowoczesność - literatura, Wydawnictwo IBL PAN, Warszawa 2012, s. 115 i n. 
narzędzia i praktyki artystyczne, co sztukę jako opartą na badaniach praktykę kulturową.

Wszystkie te nurty (a wymieniłem tylko w swoim subiektywnym mniemaniu najważniejsze) są tymczasem powiązane licznymi kanałami wzajemnych przepływów; tworzą więc raczej dorzecze niźli już wykształcone dopływy nowohumanistycznej rzeki. Jednakże, co łatwo zauważyć, ogólna tendencja jest wspólna i wyraźna. Każdy z tych nurtów kładzie mosty w miejsce murów, które wcześniej oddzielały humanistyczną refleksję od: a) sfery techniki i technologicznego instrumentarium; b) życia społecznego, polityki, historii, ekonomii, praktyk kulturowych; c) nauk ścisłych (rów wykopany w czasach antypozytywistycznego przełomu dla ochrony autonomii nauk o duchu); d) środowiska przyrodniczego (inna część owego rowu, wynoszącego człowieka ponad i poza naturę); e) sztuk pięknych, literatury i innych praktyk artystycznych, pojętych wcześniej jako przedmioty badań humanistycznych, a nie ich część składowa. W praktyce rozszerza to rzeczywiście możliwość badań na cały obszar humanistyki (w szerokim znaczeniu) oraz na jej nowe pograniczne terytoria, wszakże przy braku wyraźnych kryteriów odróżniających ją od innych obszarów badań. Do tej kluczowej kwestii powrócę w zakończeniu, by tymczasem wskazać na niektóre dylematy owych nurtów.

Humanistyka cyfrowa to najbardziej dziś rozpoznawalna, a także reprezentatywna marka nowej humanistyki oraz hasło bodaj największej rewolucji w myśleniu o jej zadaniach ${ }^{6}$, o ciągle niedających się przewidzieć możliwościach rozwojowych, a zatem również ciągle podsycanych nowych nadziejach poznawczych. Choć bynajmniej nie stawia sobie celów zastąpienia dotychczasowej specyfiki badawczej humanistyki, to stwarza wrażenie, że z tymi narzędziami zdolna jest do wszystkiego. O tych jej atutach pisano już niemało, toteż tutaj chciałbym zatrzymać się na jej - jednak - pewnych ograniczeniach, niedostatkach czy niebezpieczeństwach. Są one, według mnie, trojakiego rodzaju. Pierwsza dotyczy budowania ryzykownej rywalizacji metod jakościowych oraz ilościowych. Postawił tę kwestię na ostrzu swego autobiograficznego manifestu Franco Moretti, gdy wyznał, że zainteresował się możliwościami humanistyki cyfrowej i jej big data, kiedy zauważył, że po dziesięcioleciach zajmowania się europejską powieścią poznał kilkanaście procent produkcji powieściowej interesującego go okresu i zakresu - więc

6 Zob. np. recenzję N. Fogle z Digital Humanities, ed. by A. Burdick, J. Drucker, P. Lunenfeld, T. Presner, J. Schnapp (2012) pod symptomatycznym tytułem: Manifesto for the New Humanities, "Avant" 2013 Vol. IV, No. 2. 
budowane przez niego (i innych, wszystkich historyków literatury) uogólnienia czy syntezy były całkowicie nieuprawnione?

To spostrzeżenie jest wiele warte; ma w sobie coś z odkrycia wielkiego przeoczenia. Kiedy jednak damy już upust swemu zachwytowi dla bystrości autora i przezwyciężymy moment zawstydzenia własną ślepotą, powinniśmy zadać sobie pytanie, czy rzeczywiście są to rywalizujące ze sobą strategie badawcze i czy aby na pewno jedno warto zastępować drugim. Scjentystyczne dążenie do posiadania wiedzy pełnej i neutralnego (pozbawionego wartościowania) jej opisu nigdy nie było przecież pierwszoplanowym celem humanistyki... Nie rozwijam tego wątku szerzej; zauważę tylko, że niezależnie od tych wątpliwości są to programy, które pozwalają zadawać korpusowi przedmiotowemu inne niż dotąd pytania - i uzyskiwać inne, istotne, nowe, niekiedy fascynująco inspirujące odpowiedzi.

Wątpliwość druga dotyczy promowania owego mitu wiedzy pełnej, obiektywnej, neutralnej, uzyskiwanej dzięki cyfrowym metodom ilościowym. Mit ten maskuje przecież bardzo daleko posunięte procesy selekcji, schematyzacji oraz homogenizacji włączanego w badania "materiału”. Nie wszystko podlega badaniu, tylko to, co uda się zdigitalizować (a co nie wchodzi do bazy danych - przestaje istnieć, tj. być środowiskowo widzialne), a z tego zaś, co zdigitalizowane, dodatkowe kryteria selekcjonują poddany obliczeniom materiał. Jest on na koniec rozpatrywany w silnie zhomogenizowanej postaci, która przechodzi do porządku nie tylko nad specyfiką poszczególnych egzemplarzy, ale też samych gatunków.

Przykładowo badania nad powieścią w praktyce mogą uwzględniać jej cechy etykietalne (np. „Powieść” w podtytule) oraz repertuar cech typu idealnego, nie rzeczywistego. Tak więc nie dowiemy się z tych badań nie tylko tego, że np. utwór pt. Literatura. Powieść jest połączeniem konwencji powieściowych, testymonialno-autobiograficznych, eseistycznych, autotematyczno-metaliterackich, ale też, że sam ten gatunek ma charakter hybrydyczny. Jak zauważył Latour, duch scjentystycznej nowoczesności (utajony w humanistyce cyfrowej) promuje mit czystych gatunków... Oczywiście, cyfrowi humaniści doskonale o tym wiedzą; zadają więc przede wszystkim takie pytania (dotyczące np. cech metrycznych, stylistycznych, dyfuzyjnej wędrówki schematów fabularnych, tematów czy fabuł), których humanistyka jakościowa nie zadawała bądź na które nie znajdowała odpowiedzi.

7 Zob. F. Moretti Przypuszczenia na temat literatury światowej oraz Więcej przypuszczeń, przeł.

P. Czapliński, „Teksty Drugie” 2014 nr 4. 
Trzeci problem wiąże się z konsekwencjami rewolucyjnych przeobrażeń pola i metod badawczych. Ekstrapolując praktyki humanistyki cyfrowej do skrajnej postaci, można powiedzieć, że prowadzi ona do zastąpienia: badań tekstów (literackich i kulturowych) - opracowaniem danych (big data); teorii - aplikacjami technologicznych programów; interpretacji - wizualizacją, modelowaniem, symulacją (a więc formami opisu); zainteresowania tym, co jednostkowe, oryginalne, wartościonośne i wartościotwórcze - statystyczną analizą makrotendencji ${ }^{8}$. Sygnalizując dyskusyjne (przynajmniej dla mnie) konsekwencje tych przeobrażeń, nie zmierzam, w każdym razie, do tego, by bronić jakiegoś dotychczasowego modus vivendi między metodami jakościowymi i ilościowymi. Raczej przeciwnie: chodzi o dążenie do tego, by szukać sposobów, dzięki którym metody ilościowe mogłyby prowadzić do istotnych rezultatów jakościowych, a jakościowe, by potrafiły legitymizować swe argumentacje i wnioski nowymi ilościowymi możliwościami opisowo-analitycznymi.

Humanistyka zaangażowana dała się poznać równie wcześnie swą zmasowaną „interwencją" w środowisko społeczne i mentalne, nastawieniem na zmianę status quo (istniejących społecznych podziałów, hierarchii, uprzywilejowań i stygmatyzacji), a generalnie charakterem subwersywno-emancypacyjnym ${ }^{9}$. Warto też zauważyć, że początkowy prymat inspiracji lewicowych orientacji światopoglądowych dziś zrównoważył się udziałem (wkładem) stanowisk liberalnych, konserwatywnych czy nawet religijno-teologicznych. Pokazuje to m.in. piąte wydanie reprezentatywnego podręcznika z tego zakresu The New Humanities Reader z 2015 roku, które stanowi dobry wgląd w topografię tematyczną i metodyczną tych badań. Nie przedstawiają się one jako nowy obszar wiedzy, lecz jako humanistyczny, „ludzki wymiar” wiedzy w ogóle. Nie proponują nowej systemowej analizy ludzkiego świata, lecz raczej konstelacyjną różnorodność studiów przypadków, które ukazują związki między różnymi sposobami myślenia, metodami, polami wiedzy. Uczą (uczyć mają) kreatywnej lektury, angażującej nie tylko wiedzę, ale też doświadczenie oraz inwencję i wyobraźnię odbiorcy. Zachęcają do rozwijania „wiedzy jak", umiejętności „technicznych" i narzędziowych, radzenia sobie w sytuacjach ryzyka (eksperymentalnych), krytyczności wobec pewników

8 Zob. np. U. Pawlicka Humanistyka: pracownia, centrum czy laboratorium, w niniejszym numerze "Tekstów Drugich".

9 Mówiła o tym wcześnie E. Domańska w wywiadzie z K. Więckowską O nowej humanistyce, „Litteraria Copernicana" $2011 \mathrm{nr} 2$. 
i dogmatów, do sprawczej partycypacji w rzeczywistości kulturowej, społecznej czy politycznej ${ }^{10}$.

Zapewne nie jest to nic specjalnie nowego; raczej odnowienie XIX-wiecznego wzoru kompetencji kulturowej - kultury jako praktyki formacyjnej, raczej przymiotu jednostki (jak to określał Stanisław Pietraszko) niż przedmiotu badań... Ale nie można też powiedzieć, by nie była to dziś sprawa na nowo aktualna i ważna. Na tym polu widać najwyraźniej, że aplikatywność nowej humanistyki (jak humanistyki po prostu) oznacza przede wszystkim zdolność do „przewietrzenia” i „przemeblowania” głów jednostek i zbiorowości - tyleż w sferze idei, co postaw, zachowań, sprawczych działań, emocjonalnej wrażliwości. I niewątpliwie najlepsze książki, spektakle, artystyczne działania (także polskich autorów) taki „aplikatywny” wpływ na odbiorców osiągają.

Humanistyka kognitywna, jakkolwiek najbardziej otwarta na idee, metody i wyniki badań nauk przyrodniczych (zwłaszcza o życiu i o umyśle), jest też - o ile mogę sądzić - relatywnie w najbardziej nierównoprawnym z nimi położeniu; zderza się bowiem w praktycznych próbach współpracy z twardym stanowiskiem przedmiotowym i metodologicznym tych twardych nauk (mimo całej demokratycznej, koncyliacyjnej i ekumenicznej ideologii, którą ta współpraca bywa otaczana). Można powiedzieć, że jesteśmy w tym obszarze ciągle jeszcze w stadium kapitalizmu monopolistycznego; jak u Forda, gdzie klient mógł wybrać każdy kolor samochodu, pod warunkiem, że będzie to kolor czarny - tak i relacje ze „ściślakami” (jak ich humaniści przezywają) są na co dzień determinowane przez twarde przekonania o ich monopolu na wiedzę ścisłą, pewną i pełną. Pomoc, która nadchodzi ze strony etnologów, socjologów i filozofów nauki - Latoura, Knorr-Cettiny i innych - ukazujących subiektywne, mentalne, społeczne, kulturowe, polityczne uwarunkowania czysto naukowych na pozór badań laboratoryjnych napawa nadzieją (na dalszą jednak dopiero metę), dostarcza tymczasem inspiracji, a także narzędzi budowania takich pomostów rzeczywistej wymiany (punktów widzenia) czy współpracy.

Otwarcie nowego rozdziału rzeczywistej współpracy wydaje się wszakże możliwe dopiero po wypracowaniu wspólnego pola badań, na którym zainteresowania problemowe i punkty widzenia (humanistyczne i kognitywne) mogłyby się spotykać i negocjować swoje racje.

10 Zob. The New Humanities Reader, ed. by R.E. Miller, K. Spellmeyer, Cengage Learning, Stanford 2015, s. XXII-XXXIV. 
Niewykluczone, że taką stymulującą rolę może odegrać kategoria „ucieleśnionego umysłu" (obecna zresztą od dawna w badaniach lingwistycznych i antropologicznych) - przynajmniej, jeśli sądzić o tym po publikacji (przełomowego może) tomu The Cognitive Humanities: Embodied Mind in Literature and Culture ${ }^{11}$.

Posthumanistyka z kolei budzi chyba dziś największe spory ideowe, światopoglądowe, filozoficzne ${ }^{12}$ - co zdaje się wskazywać na wagę podejmowanych zagadnień oraz jej rosnące znaczenie dla humanistyki w ogóle. Studia nad rzeczami, materialnością, środowiskiem przyrodniczym, światem roślinnym i zwierzętami, rozwijane w jej ramach od rozmaitych stron dochodzą do granic, opukują trwałość bariery antropologicznej oraz możliwości poszerzenia obszaru antropologicznego poznania. Ze swej strony idę tu za dwiema inspirującymi dla mnie wskazówkami. Jedną zawdzięczam Robertowi Esposito, który zauważył, że zarówno u Heideggera (w jego Liście o humanizmie), jak i u Sartre'a (w jego Egzystencjalizm jest humanizmem - oba teksty z 1946 roku), w ich przełomowych studiach ,jeszcze żadne z początkowych filozoficznych założeń - odrzucenie biologicznego pojęcia natury ludzkiej, absolutne przeciwstawienie człowieka innym gatunkom żyjącym, niedocenienie ciała jako pierwotnego wymiaru egzystencji - nie zostaje rzeczywiście poddane dyskusji"13. A dyskusja nad tymi problemami stała się właśnie udziałem refleksji posthumanistycznej. Druga inspirująca wskazówka pojawia się u Latoura, który zauważył, że

stoimy nie tylko w obliczu ryzyka przegapienia wszystkiego, co interesujące w bytach, na które natyka się antropologia osobliwie zwana „kulturową" lub „społeczną", ale nadto ryzykujemy również i to, że nie oddamy nawet sprawiedliwości temu czemuś, co jeszcze dziwniej określa się jako "materialność", którą uczyniono „tamtą stroną" zgłębianą podobno przez antropologię fizyczną. [...] Niezależnie od etymologii, nie ma żadnego powodu, by antropologia pozostawała antropocentryczna. Oznacza to jedynie tyle, że dyscyplina ta jest szczególnie zainteresowana pewnymi

11 The Cognitive Humanities: Embodied Mind in Literature and Culture, ed. by P. Garratt, Palgrave Macmillan, London 2016.

Zob. np. rozważania A. Bielik-Robson Nowa Humanistyka w poszukiwaniu granic, w niniejszym numerze "Tekstów Drugich".

13 R. Esposito Polityka i natura ludzka, przeł. K. i M. Burzykowie, w tegoż Pojęcia polityczne. Wspólnota, immunizacja, biopolityka, wstęp M. Burzyk, Universitas, Kraków 2015, s 145. 
punktami styku tych czynników sprawczych (agencies) oraz pewnymi figurami historycznymi kojarzonymi z określeniem „człowieczeństwo”.14

Ryzykując karykaturalne uproszczenie, powiedziałbym, że posthumanistyka rozpatruje człowieka w środowisku „kulturonatury” (zwrotnego sprzężenia między kulturą i naturą, historią i przyrodą, tym, co społeczne, i tym, co biologiczne...).W tym kontekście, po pierwsze, sam człowiek ujmowany jest jako 'hybryda' w typie „zwierzoczłekoupiora” (że posłużę się znowu aktualnym literackim wynalazkiem pojęciowym Konwickiego); psychocielesnej istoty owładniętej przez zmory przeszłości, widma przyszłości oraz fantazmaty pragnień i afektywnych pobudzeń... A nie jako ów sławny ongiś Monsieur Teste (figura wykreowana przez Paula Valéry'ego); czysty intelekt, samowładny pan swego losu i władca stworzenia (lokowany ponad i poza środowiskiem biologiczno-przyrodniczo-materialnym). A po drugie, i człowiek, i kultura nie mogą być już sytuowani na zewnątrz - i w opozycji do - natury, lecz suplementarnie: w środowisku wzajemnie sprawczej partycypacji.

Ostatni nurt, na który chcę zwrócić uwagę, tworzą badania oparte na sztuce, posługujące się sztuką, art based research, które znajdują swe dopełnienie w wykorzystaniu badań humanistycznych przez sztukę (zwłaszcza sztukę tzw. nurtu krytycznego). Funkcją tego niezbyt fortunnego określenia - humanistyka artystyczna - jest wskazanie na wzajemne związki między tymi dziedzinami praktyk poznawczo-kulturowych. Badania posługujące się sztuką mają dwudziestoparoletnią tradycję, a w Polsce rozwijają się bardziej systematycznie i świadomie chyba dopiero od kilku lat ${ }^{15}$ i pomału emancypują się ze środowiska humanistyki zaangażowanej. Łączą bowiem podejścia wynikające z zaangażowania w społeczne problemy z ujęciami nauk społecznych

14 B. Latour Wyrywajg̨c się snom i spekulacjom - prezentacja AIME, przeł. K. Abriszewski, w: Kolokwia antropologiczne. Problemy współczesnej antropologii społecznej, red. M. Buchowski, A. Bentkowski, Wydawnictwo Nauka i Innowacje, Poznań 2014, s. 581, 583.

15 Zob. m.in.: E.W. Eisner The Enlightened Eye. Qualitative Inquiry and the Enhancement of Educational Practice, Prentice Hall, Upper Saddle River, New York 1998; G.L. Ulmer Heuretics. The Logic of Invention, John Hopkins University Press, Baltimore-London 1994; S. Finley Badania posługujące się sztuką. Rewolucyjna pedagogika oparta na performansie, przeł. M. Podgórski, w: Metody badań jakościowych, t. 2; M. Kosińska Między autonomiq a epifaniq̨. Art based research, badania jakościowe i teoria sztuki, „Sztuka i Dokumentacja” 2016 nr 14; T. Rakowski Sztuka w przestrzeniach wiejskich ieksperymenty etnograficzne. Pożegnanie kultury zawstydzenia:jednoczasowość, zwrot ku sobie, proto-socjologia, "Teksty Drugie” 2016 nr 4. Zob. też klasyczną pracę S.K. Langer, antycypującą m.in. afektywny zwrot w badaniach nad sztuką, Feeling and Form. A Theory of Art, Charles Scribner's Sons, New York 1953. 
tzw. zorientowanych na działanie oraz różnymi formami artystycznymi (narracyjnymi, performatywnymi, wizualnymi). Artystyczny eksperyment zostaje tu potraktowany jako jeden ze sposobów konstruowania humanistycznego poznania, i to takiego, które wykracza poza granice języka i pojęciowej racjonalności. Badania oparte na sztuce zmierzają w ten sposób do poszerzenia granic poznania oraz wiedzy o ludzkich zdolnościach, funkcjach i formach pojmowania, a także sposobach formowania tożsamości, postaw sprawczego działania, struktury odczuwania, afektywnego podłoża więzi wspólnotowych etc. Klasyczne, ważne, inspirujące prace Susanne Langer (co podkreślam z satysfakcją) doczekały się tu wreszcie należnej im uwagi, interpretacji, uznania.

\section{4 .}

W kontekście tak zarysowanej - bardzo subiektywnej - topografii ważniejszych nowohumanistycznych stanowisk chciałbym krótko rozważyć przypadek ewolucji refleksji teoretycznoliterackiej, której jeden z nurtów pilotowałem. Chodzi o KTL - kulturową teorię literatury ${ }^{16}$, stanowiącą parę lat temu zespołową propozycję na „okres przejściowy” między stadium dojrzałości nowoczesnej teorii literatury a rodzącymi się wówczas, współczesnymi jej mutacjami, wcieleniami i metamorfozami.

Najlepszą okazją do rozważenia tej dojrzałej fazy strukturalnego myślenia o teorii literatury jest lektura słownikowej definicji opracowanej przez Janusza Sławińskiego, w której pierwszym zdaniu czytamy, że jest to

gałąź nauki o literaturze obejmująca dociekania nad prawidłowościami strukturalnymi i ewolucyjnymi literatury jako odrębnej dziedziny aktywności humanistycznej, ogólnymi właściwościami dzieł literackich i ich typologicznym zróżnicowaniem, w pewnym zakresie także nad mechanizmami procesu twórczego i odbioru dzieł literackich. ${ }^{17}$

Definicja ta, choć posługuje się jednym z ulubionych „elastycznych” określeń Sławińskiego („dociekania”), jest popisem myśli systemowej i systematycznej

16 Kulturowa teoria literatury: główne pojęcia i problemy, red. M.P. Markowski, R. Nycz, Universitas, Kraków 2006; Kulturowa teoria literatury 2: poetyki, problematyki, interpretacje, red. T. Walas, R. Nycz, Universitas, Kraków 2012.

17 J.Sławiński Teoria literatury, w: Słownik terminów literackich, red. J. Sławiński, wyd. 3 poszerzone i poprawione, Ossolineum, Wrocław 1998. 
- systemami (bądź „systemoidami”) są dzieło, gatunek, konwencje, literatura (jako „system norm żyjących w historii”), teoria literatury i - jako całość nadrzędna - nauka o literaturze. W jej gmachu wszystkie normatywne porządki mają swoje miejsce: od elementarnych "typowych jednostek językowo-konstrukcyjnych" po "tradycję literacką" oraz kierunki i szkoły badawcze. Tak pojęta teoria literatury jest „uogólnieniem i schematyzacją" cząstkowych opracowań zadań badawczych, wypracowuje kategorie, które porządkują te badania szczegółowe i włączają je w „spójny kompleks wiedzy o literaturze” (zauważmy to typowe dla Sławińskiego retoryczne „poluźnienie” gorsetu pozytywistycznego z ducha modelu naukowości: od systemowej nauki o literaturze do spójnego kompleksu wiedzy o literaturze).

Tak pojęta teoria literatury nie straciła, można powiedzieć, nic ze swojej wartości, tyle że wartość ta stawała się coraz bardziej historyczna. Dalej może być - i była - uprawiana; np. główne teoretyczne i metodologiczne ujęcia studiów kulturowych przejęły większość strukturalistycznych założeń tej teorii badawczej. Problem podstawowy leży chyba w tym, że pytania (dotyczące zasadniczo wewnętrznego uporządkowania literatury), na które mogła dać odpowiedzi, przestały być uznawane za ważne czy interesujące zastanówmy się, jak często np. pisze się dziś i czyta prace o strukturze narracyjnej, relacji między fabułą i sjużetem, narratorem i bohaterem, przestrzenią i czasem, opisem i opowiadaniem etc., etc.? Toteż sam, kiedy próbowałem dać definicję słownikową „teorii literatury” w 2000 roku, chciałem uszanować ten historyczny (w obu znaczeniach tego słowa) status tej kategorii - oraz tej koncepcji uprawiania teorii w racjonalnym i systemowym duchu nowoczesności - pisząc w pierwszym zdaniu, że jest to "dział wiedzy o literaturze obejmujący usystematyzowany zespół ogólnych twierdzeń o istocie, odmianach, prawidłowościach (strukturalnych i ewolucyjnych) literatury"18.

Tak pojmowana, nie mogła dać, siłą rzeczy, odpowiedzi na pytania, po co ludzie piszą i czytają literaturę oraz co w niej jest takiego - mimo sterylności, ogólności i schematyczności jej strukturalnych kategorii - co sprawia, że te zadania i potrzeby (egzystencjalne, światopoglądowe, społeczne...) przecież skutecznie spełnia. Oczywiście można argumentować, że te pytania nie były bynajmniej nieznane, ale że uznano je za nieprofesjonalne czy niespełniające standardów „naukowości” nowoczesnej teorii literatury. Rzecz jednak

18 R. Nycz Teoria literatury, w: Literatura polska XX wieku. Przewodnik encyklopedyczny, PWN, Warszawa 2000. 
w tym, że poglądy na ten temat, a w rezultacie również formuła i charakter zadań poznawczych, istotnie się zmieniły...

Pomysł kulturowej teorii literatury wydawał się obiecującym projektem badań nad tymi kwestiami przede wszystkim dlatego, że miał obejmować zarówno kulturowe (w szerokim rozumieniu) wymiary tekstów literackich, jak i kulturowe (nie tylko normatywnie literaturoznawcze) sposoby ich czytania i analizowania. Od początku nie zakładał jednak (bo nie mógł i nie chciał) podtrzymania "naukowego" statusu teorii jako wytworu racjonalnej myśli systemowej i systematyzującej. „Teoriami” były tu różnorodne „studia” i "zwroty”, a więc raczej koncepty badawcze (rozwijające się z kluczowych pojęć, takich jak gender, postkolonializm, pamięć, performans, afekt itp.), teorie in statu nascendi, teorie w procesie, „praktykowania teorii”, które stanowiły raczej projekty inicjowanych programów badawczych niźli finalne wytwory systemowego ujęcia danej dziedziny przedmiotowej. Na Zachodzie był to zresztą czas wygasania "literackich teorii”, potem teorii „, bezprzymiotnikowej" i „bezprzydawkowej” (jak w znanym ujęciu Jonathana Cullera), a jeszcze później po prostu "studiów literacko-kulturowych", w ramach których „teoria” przestaje już pełnić funkcję naczelnej kategorii operacyjnej (jak myślę, właśnie z powodu zmiany zakresu i funkcji tej formuły działalności badawczej).

Sądzę dzisiaj, że niezależnie od ekscentryczności (czy nawet dziwaczności) nazwy - ponieważ można argumentować: albo teoria literatury, albo kulturowa teoria czy studia - kulturowa teoria literatury miała rację bytu, była potrzebna, a poza tym była właśnie nurtem ekwiwalentnym w stosunku do owych studiów literacko-kulturowych. Instytucjonalną formułę nadały im, dla przykładu, w USA wielokrotnie wznawiane podręczniki Roberta Dale Parkera $^{19}$, a w Europie niedawno opublikowane opracowanie Naomi Segal i Danieli Kolevej pt. From Literature to Cultural Literacy ${ }^{20}$. Szczególnie ten ostatni tom wydaje się wart krótkiego komentarza - i ze względu na kategorię „kulturowej piśmienności”, i z uwagi na sformułowany tam program (a raczej wyrażoną wolę) sprofilowania przedmiotowego i metodologicznego prowadzonych współcześnie badań. Ta pierwsza urasta dziś do roli nadrzędnego

Zob. R.D. Parker How to Interpret Literature: Critical Theory for Literary and Cultural Studies, $3^{\text {rd }}$ edition, Oxford University Press, New York 2015; R.D. Parker Critical Theory: A Reader for Literary and Cultural Studies, Oxford University Press, New York 2012.

20 From Literature to Cultural Literacy, ed by N. Segal, D. Koleva, Palgrave Macmillan, London 2014. Zob. przekład Wprowadzenia do tego tomu N. Segal (przeł. E. Kołodziejczyk), w niniejszym numerze "Tekstów Drugich". 
pojęcia-parasola w humanistyce, o znaczeniach i funkcjach oddalających się zdecydowanie od filologicznie pojętej „piśmienności” (np. w opozycji do „oralności"), co było zresztą widać już dawno w tradycji amerykańskiej, choćby w tytule bestselleru sprzed lat wybitnego badacza literatury E.D. Hirscha Cultural Literacy: What Every American Needs to Know [Kulturowa piśmienność: co każdy Amerykanin wiedzieć powinien $]^{21}$. Chodzi tu więc przede wszystkim o rodzaj kulturowej kompetencji, ogłady czy obycia, jak dawniej mówiono a więc „wiedzy jak” (nie „wiedzy że”, wedle dawnego rozróżnienia Gilberta Ryle'a), pozwalającej na sprawne i skuteczne funkcjonowanie w społeczeństwie i współczesnej kulturze (również technologicznej).

Ten drugi zaś motyw wydaje się podjęciem kluczowego zadania, jakim jest próba „tożsamościowego" sprecyzowania (dookreślenia, sprofesjonalizowania) współczesnych badań humanistycznych zajmujących się nieomal niczym nieograniczoną różnorodnością przedmiotów i problemów w sposób na pozór skrajnie hybrydyczny, pozbawiony wszelkiej jednorodności czy odrębności metodologicznej. Propozycja ta tymczasem dotyczy wyodrębnienia czterech kluczowych kategorii, mających ukierunkowywać, a może i modelować prowadzone studia literacko-kulturowe, a mianowicie: tekstualności, fikcjonalności, retoryczności i historyczności.

Uważam, że jest to dobry kierunek, wart z pewnością rozwinięcia, uszczegółowienia, krytycznego sprawdzenia jego operacyjnych możliwości (choć jesteśmy tu na samym początku drogi...). Ze swej strony próbuję iść drogą nieco inną (ale tylko nieco inną). Od kilku lat bowiem zaczynam wykład o KTL od wyjaśnienia, że tytułowy akronim zachowuje pełną ważność, natomiast jego zakres i teoretyczno-metodologiczna zawartość pomału się zmieniają, mianowicie: od kulturowej teorii literatury do kulturowych tekstów lektury. Tym trzem ostatnim słowom chciałbym poświęcić krótkie wyjaśnienia.

Po pierwsze, uważam, że mamy pełne prawo zajmować się dalej tekstami, oczywiście w węższym i szerszym znaczeniu i bez ograniczania się wyłącznie do tekstów zwanych literackimi. I ze względu na gigantyczną profuzję oraz niesłabnącą rolę różnego, w tym zupełnie nowego, rodzaju produkcji tekstowej (oralnej i piśmiennej) we współczesnej cyberkulturze, życiu publicznym i codziennym. I z uwagi na to, że inne praktyki - wizualne, dźwiękowe, działaniowe, performatywne - nabierają statusu tekstów kulturowych (tu, w opozycji do naturalnych przedmiotów, będącym obiektami badań nauk ścisłych

21 E.D. Hirsch Jr Cultural Literacy: What Every American Needs to Know, Vintage Books, New York 1988. 
i przyrodniczych) przez to, że są semiotycznie zorganizowanymi obiektami i praktykami znaczącymi'22.

Po drugie zatem, ich znaczenia trzeba by pojmować wyraźnie szerzej niż tylko jako pojęciową treść (zawartość) wyrażeń językowych - i to zarówno w odniesieniu do tekstów językowych, jak i kulturowych (pozajęzykowych). Nawiązując do uwag poczynionych gdzie indziej ${ }^{23}$, powiedziałbym tak: jeśli zachować rozumienie interpretacji jako intelektualnej procedury przypisywania znaczenia niezrozumiałym miejscom tekstu w rezultacie zidentyfikowania kontekstu, w obrębie którego zyskują one sens, budujący semantyczny porządek całości, to poza nią pozostają co najmniej dwa obszary istotnych znaczeń. Pierwszy obejmuje prejęzykowe i prepojęciowe „odczucia” znaczenia, o charakterze emergentnym, bezwiednym, samowzbudnym, wynikające z naszego udziału w doświadczeniowej wspólnocie (w której znajdują się też owe teksty, praktyki, zachowania). Drugi zaś - „postpojęciowe” efekty (cielesne, afektywno-doznaniowe) siły oddziaływania, transmisji tych prepojęciowych, pozapojęciowych i pojęciowych znaczeń.

Potocznie przecież wszystkie je nazywamy znaczeniami; kiedy mówimy o czymś (jakimś zachowaniu, postawie, wydarzeniu), że wiemy o co chodzi, że coś nam mówi (chce powiedzieć), że ma znaczenie, że coś mamy na myśli, że jest dane do zrozumienia... Można by powiedzieć, że owo pojęciowe znaczenie jest otoczone, przeniknięte, pobudzane przez znaczenia pozapojęciowe (które też może pobudzać). Ale pewnie trafniej byłoby rzec, że faktycznie mamy do czynienia ze „znaczeniem ucieleśnionym”" ${ }^{24}$, hybrydycznym w swoim charakterze, a rozciągającym się od znaczenia ciała, przez wspólnotowo

To rozróżnienie na przedmioty fizyczne, badane przez przyrodoznawców - które "tylko są", oraz przedmioty kulturowe, stanowiące część kulturowej rzeczywistości - które "nie tylko są, ale i znaczą", ma długą tradycję w myśli XX wieku. Przy innej okazji wyprowadzałem je z myśli S. Czarnowskiego, ale m.in. i R. Ingarden był rzecznikiem tego rozróżnienia. Rozważając różnicę między własnością a wartością przedmiotu, zauważał, że ta pierwsza przysługuje każdemu, ta druga zaś jest pewnym naddatkiem, który „nadaje przedmiotowi pewną dignitas, pewien zupełnie nowy aspekt jego istnienia, jakiego by bez niej nigdy nie zdołał osiągnąć. Wynosi go w bycie ponad wszystkie przedmioty wartości pozbawione, które tylko są, istnieją, lecz nic nie znaczą" (R. Ingarden Przeżycie, dzieło, wartość, Wydawnictwo Literackie, Kraków 1966, s. 100).

Zob. uwagi w szkicu Literatura: litery lektura. O tekście, interpretacji, doświadczeniu rozumienia i doświadczeniu czytania. Z dodaniem studium przypadku "Wagonu” Adama Ważyka, w: Poetyka doświadczenia..., s. 301 i n.

24 Zob. M. Johnson Znaczenie ciała. Estetyka rozumienia ludzkiego, przeł. J. Płuciennik, Wydawnictwo Ut, Łódź 2015. 
podzielane znaczenia „ciała” społecznego, po znaczenia wpisane w środowisko „kulturonatury”, a pobudzane przez „afordancje” (określenie Jamesa Gibsona) ekosystemu; tu rozumiane jako swego rodzaju znaczeniowe „oferty”, sygnalizowane w relacjach z nami przez środowisko.

Dwa proste przykłady przybliżą, mam nadzieję, tę nazbyt skrótową charakterystykę. Pierwszy. Kiedy Charles Baudelaire rozpoczyna swój sławny Spleen nie mniej sławną frazą: „Kiedy niebo jak ciężka z ołowiu pokrywa...” (w przekładzie Bolesława Wieniawy Długoszowskiego), to robi naraz trzy rzeczy (co najmniej). Po pierwsze, wynajduje obrazowe określenie na pozostające dotąd bez tak sugestywnej wyobrażeniowo formuły doświadczenie psychicznego przygnębienia, depresji, melancholii (określenie nowe, acz aktywujące wcześniejsze tradycje, np. średniowieczne wyobrażenia nieba jako sklepienia, a nie otwartego, niczym nieograniczonego przestworu, jak np. u Szymborskiej). Po drugie, pojęciowo dookreśla znaczenie tego obrazu (poczucie przytłoczenia człowieka, jakby przygniecionego ciężarem wielkiej ołowianej pokrywy). Po trzecie, siła oddziaływania tego obrazu, przejmowanego przez licznych czytelników na własny użytek, przyczyniła się niewątpliwie do popularności całego utworu, a odegrała też inspiratorską rolę, wpływając na twórczość wielu innych pisarzy przełomu XIX i XX wieku (u nas zwłaszcza poetów tworzących dekadenckie „krajobrazy duszy”).

Przykład drugi. Kiedy Joanna Rajkowska stworzyła Pozdrowienia z Alej Jerozolimskich (czyli palmę na rondzie de Gaulle'a w Warszawie), to również zrobiła trzy rzeczy (co najmniej). Po pierwsze, aktywowała poczucie „bliskości", rodzaj więzi afektywno-doświadczeniowej między społecznościami i narodami - Polakami i Żydami - ongiś sąsiedzkimi, a dziś odizolowanymi (przestrzennie, czasowo, barierą śmierci, traum pamięci, mentalnych konfliktów etc.). Uczyniła to estetycznie łagodnymi (w tym sensie neutralnymi politycznie) środkami plastycznego gestu (instalacją owej palmy), za sprawą którego sztuczna imitacja naturalnego elementu pejzażu izraelskiego ewokuje złożone konteksty kulturowe, a także historyczną motywację na pozór arbitralnej nazwy ulicy (gest podobnego rodzaju wykonał potem dużo intensywniejszymi środkami Rafał Betlejewski w „Tęsknię za Tobą, Żydzie”). Po drugie, pojęciowa formuła pocztówkowego "pozdrowienia” buduje, na poziomie dyskursywnego przekazu, „przyjazny” typ komunikacyjnej relacji na odległość - i, można powiedzieć, stabilizuje (performatywnie) tę relację jako „przyjazną na odległość”. Po trzecie, siła oddziaływania tego gestu, który był też nader udaną interwencją w społeczną wrażliwość i mentalność, zainicjowała bardzo bogatą historię funkcjonowania palmy w życiu miasta 
i jego mieszkańców, w toku której nabrała cech kulturowego palimpsestu oraz węzła skonfliktowanych polityk pamięci.

Ta z pewnością nazbyt upraszczająca charakterystyka miała służyć jedynie potrzebie unaocznienia konieczności rozszerzenia pola i postaci semantycznej aktywności „tekstów kulturowych”, które ogarnąć musi ich lektura. Pojęcie czytania/lektury może, jak sądzę, pełnić dziś funkcję "metakategorii” analitycznej ze względu na swoje cechy, obecne zresztą i w potocznym użyciu: akcentuje procesualność (nie rezultat), cząstkowość czy aspektowość (nie: finalność czy pełnię), aktywność podmiotu jako warunek aktywowania znaczenia (partycypację, nie kontemplację czy obserwację), relacyjny oraz interakcyjny charakter znaczenia (a nie znaczenia jako określonego sensu zdeponowanego w danym miejscu, ukrytego w tekście). A przede wszystkim: podkreśla usytuowanie i podmiotu, i tekstu w tej samej przestrzeni, i w tych samych rolach czynników sprawczych, uczestniczących w tej samej wewnętrznej przestrzeni rzeczywistości kulturowej (a nie sytuowanych po przeciwnych stronach poznawczej barykady).

Czytanie/lektura, jako proces mediacyjnej organizacji związków między tymi podmioto-przedmiotami, staje się nosicielem znaczenia oraz medium partycypacyjnego poznania kulturowego. I na koniec; czytanie/lektura może (a nawet powinno) być traktowane jako kwintesencja czy ucieleśnienie (testowanie w empirycznym działaniu) literaturoznawczych kompetencji, wyposażających w narzędzia do rozwiązywania najbardziej złożonych zagadek tekstów kulturowych, „wiedzy jak” - jak radzić sobie w świecie znaczeń "kulturonatury” (w którym notabene tradycje semiotyki kultury z pewnością są aktywnie obecne). Z tym wszystkim, sygnalizowane tu: status tekstu kulturowego, charakter ucieleśnionego znaczenia, koncepcja czytania/lektury - to oczywiście dopiero pierwsze wskazówki, określające punkt wyjścia pożądanego projektu metodologicznego.

\section{5.}

Nakreślonych wyżej naprędce pięć głównych wariantów rozwojowych nowej humanistyki to jedynie próba roboczej topografii stanowisk, wokół których zaczynają się stopniowo koncentrować (na to przynajmniej wychodzi z tej analizy) liczne studia i zwroty, pleniące i rozrastające się tak obficie w ostatnim ćwierćwieczu. Mimo całej odmienności, różnokierunkowości celów i strategii mają one uderzające cechy wspólne (łącznie z osobno charakteryzowanym nurtem badań literacko-kulturowych czy KTL), czemu na koniec 
chciałbym poświęcić uwagę. Jest ich sporo, tu jednak tylko o trzech bodaj najważniejszych.

Świat nowej humanistyki to, po pierwsze i przede wszystkim, świat immanencji, rzeczywistość partycypacji, poznania od wewnątrz, poznania uczestniczącego. Widać to dobrze w każdym z wariantów. Humanistyka cyfrowa pracuje w „kulturze uczestnictwa”. Humanistyka zaangażowana jest formą interwencji, niekiedy nawet dość inwazyjnego poruszenia spetryfikowanych postaw, przedsądów, zachowań danej wspólnoty czy zbiorowości. Humanistykę kognitywną charakteryzuje partycypacyjna pozycja podmiotu jako "podmiotu w środowisku”. Posthumanistykę - ekosystem „kulturonatury” jako uniwersum podmiotowej aktywności. Humanistykę artystyczną - inkluzja sztuki jako narzędzia i medium twórczego poznania. Tę specyfikę nowohumanistycznego poznania sformułowała najradykalniej Kirsten Hastrup, stwierdzając: „nie możemy w żaden sposób dotrzeć do rzeczywistości, jeśli nie staniemy się jej częścią"25.

Słychać tu niewątpliwie pogłos Nietzscheańskiej proklamacji performatywnego (jak byśmy dziś powiedzieli) poznania: „prawdy się nie poznaje; prawdą się jest" oraz jego prognozy zastąpienia obiektywizmu - perspektywizmem. Generalnie rzecz biorąc zaś, mamy do czynienia z wyraźnym przeciwstawieniem się nowoczesnemu (i neopozytywistycznemu) ideałowi poznania jako dokonywanego z metajęzykowej perspektywy zewnętrznego oglądu bezstronnie, neutralnie, obiektywnie postrzeganych rzeczy (istniejących uprzednio i niezależnie od aktu poznania). Rozwijanie humanistycznych badań warunkowanych tą ontologiczno-epistemologiczną specyfiką to niewątpliwie w dużej mierze nowe oraz atrakcyjne poznawczo zadanie.

Ta kultura partycypacji, w którą, zdaje się, weszliśmy, ma też swoje konsekwencje. Uwrażliwia na rozmaite formy, także bezwiednego, udziału, na dwuznaczność pozycji świadka, biernego widza (stymulując, jak sądzę, m.in. współczesną refleksję nad historycznymi przejawami pozycji bystandera w czasach Zagłady), na trudność - jeśli w ogóle możliwość - obsadzenia (się) w roli niezaangażowanego obserwatora. Ma ona także swe niewygody czy nawet niebezpieczeństwa, jakimi są poczucie „uwięzienia w immanencji” i niedostępność metajęzykowej pozycji poznawczej, umożliwiającej przyjęcie

25 K. Hastrup Social anthropology. Towards a pragmatic enlightenment, "Social Anthropology" 200513 (2); cyt za: E. Klekot Rozpoznawanie topografii, w: Kolokwia antropologiczne. Problemy współczesnej antropologii społecznej, red. M. Buchowski, A. Bentkowski, Wydawnictwo Nauka i Innowacje, Poznań 2014, s. 76. 
holistycznej perspektywy i bezstronnego dystansu oraz urzeczywistniającej zdolność do transcendowania wszelkich uwarunkowań sytuacyjnych. Stąd być może zresztą bierze się nowa atrakcyjność alternatywnych koncepcji, nawiązujących np. bezpośrednio do tradycji kantowskiej ${ }^{26}$.

Drugą uderzającą cechą jest prymat „wiedzy jak”, narzędzi, sprawności kompetencyjnych, widoczny również w każdym właściwie z nurtów nowohumanistycznych badań. Zapewne najbardziej to wyraźne w humanistyce cyfrowej, która manifestacyjnie podkreśla ten swój „instrumentalny” charakter jako zespół nowych, potężnych narzędzi potencjalnie zdolnych do wszystkiego, a tymczasem poszukujących godnych siebie wyzwań i zadań. Nie mniej to wyeksponowane w badaniach nad kulturową piśmiennością, które wprost definiują się w kategoriach kompetencyjnych sprawności, nowego rodzaju cywilizacyjnej „ogłady”, która winna być dziś przymiotem każdej jednostki. Współczesny prymat czytania/lektury oraz "teorii” jako konceptu inicjującego pewien proces i projekt badawczy - to również efekt odejścia od standardów teorii nowoczesnej, z jej naciskiem na podsumowującą wyniki szczegółowe, sfinalizowaną i usystematyzowaną wiedzę ogólną - a więc propozycjonalną, pojęciową „wiedzę że”.

Jak rozumiem, nie chodzi o zastąpienie jednej przez drugą, raczej o próbę wyprowadzenia celów (w tym nowych zadań badawczych) ze środków, nowych narzędzi, ujęć, konceptów - a nie o dobieranie czy podporządkowanie owych środków arbitralnie ustanowionym doktrynalnym celom. Bowiem to właśnie owe próbne koncepty teoretyczne, badawcze hipotezy stwarzają możliwość pozyskania rzeczywiście nowej wiedzy przedmiotowej, a nie ekstrapolacje obowiązującej teorii naczelnej na kolejne obszary... I w tej właśnie postaci przejawia się ta cecha najdobitniej w pozostałych nurtach nowej humanistyki - zaangażowanej, kognitywnej, artystycznej, oraz posthumanistyki.

Wreszcie ostatni zespół powinowactw: zainteresowanie procesem (raczej, niż jego rezultatami czy esencjalnymi własnościami niezmiennych obiektów) - procesem twórczym, odbiorczym, procesem zmiany, praktykami (raczej, niż teoriami w starym stylu), czynnościową stroną kulturowej i społecznej rzeczywistości jako niezbędnie równoważną dla trwania i rozwoju człowieka wego i kosmopolitycznego, przeł. R. Rakowski, J.S. Wasilewski, oraz T. Rakowski Nieustajq̨ca zdolność do działania. Nigela Rapporta antropologia wolności - oba teksty w: Kolokwia antropologiczne... 
i kultury. Stąd koncentracja na badaniach procesów dyfuzji i obiegów kulturowych elementów w laboratoriach humanistyki cyfrowej; na programach "interwencyjnych” i badaniach społecznej aktywności czy zmiany w humanistyce zaangażowanej; na wzajemnych oddziaływaniach człowieka i środowiska (w tym środowiska „kulturonatury”) w humanistyce kognitywnej i posthumanistyce; na posługiwaniu się sztuką jako performatywną praktyką kulturową w humanistyce artystycznej. Stąd również „naturalne” rozszerzanie tak ukierunkowanych badań na problematykę twórczości, kreatywności, nowości czy innowacyjności (które o wywołanych przez te procesy zmianach w dotychczasowych stanach rzeczy ex post zaświadczają). Z tej perspektywy nawet to, co było widziane jako synonim jedności i tożsamości - człowiek i kultura - ukazuje swoje procesualne, zmienne, hybrydyczne, kreatywne, „czasownikowe” oblicze.

\section{*⿻一从火}

Pozwolę sobie zakończyć anegdotą (trochę z własnego podwórka). Interesując się tą problematyką, przygotowałem wykład i byłem bardzo zadowolony z wymyślonego przez siebie tytułu dla niego: Kultura jako czasownik, który wygłosiłem w maju 2014 roku w ramach Copernicus Festival. Satysfakcja z własnej oryginalności i inwencji nie trwała jednak długo: na początku 2015 ukazał się (często tu przywoływany) tom Kolokwia antropologiczne (z datą 2014), w którym znalazł się tekst wykładu Tima Ingolda pt. To Human is a Verb, przetłumaczony przez Ewę Klekot jako „Człowieczyć” to czasownik (skrócony przekład tego tekstu ukazał się wcześniej, pod koniec 2014 w „Autoportrecie”, pod jeszcze bardziej podobnym do mojego tytułem: Człowiek to czasownik ${ }^{27}$. Nie przywołuję tego przykładu po to, by się chwalić pierwszeństwem - to zresztą nie byłaby prawda: Ingold wygłosił swój wykład nieco wcześniej niż ja; a jako chętny czytelnik pism tego bardzo cenionego przeze mnie antropologa wiem, że wcześniej zajmował się m.in. kategorią „improwizacji kulturowej”, która tę problematykę już trochę zagarniała...

Traktuję - i dlatego tu przywołuję - to doświadczenie jako ewidentne (dla mnie przynajmniej) świadectwo zachodzenia faktycznej, teoretyczno-metodologicznej i praktycznej, zmiany w humanistyce tego zglobalizowanego

27 Zob. R. Nycz Kultura jako czasownik, wykład, https://www.youtube.com/watch?v=PpiAuOxWfzg; T. Ingold "Człowieczyć" to czasownik, w: Kolokwia antropologiczne...; T. Ingold Człowiek to czasownik, "Autoportret" $2014 \mathrm{nr} 4$. 
świata; kiedy i w centrum, i na peryferiach, w głowach i praktykach światowej czołówki oraz lokalnych majsterkowiczów humanistycznego instrumentarium rodzą się podobne pomysły, projekty badawcze, następuje podobnie przebiegająca a nieoczekiwana wcześniej zmiana miejsc (stanowisk, punktów widzenia). Stąd pewnie bierze się subiektywny, a zarazem niepewnie optymistyczny charakter tego szkicu - któremu na dodatek towarzyszy niepokojące (bo starcze) wrażenie, że po ćwierćwieczu jakbym się powtarzał o nowohumanistycznych poszukiwaniach: nie wiemy, czy będzie lepiej, jeśli będzie inaczej, ale chyba musi być inaczej, jeśli ma być lepiej.

\section{Abstract}

\section{Ryszard Nycz}

JAGIELLONIAN UNIVERSITY (CRACOW), THE INSTITUTE OF LITERARY RESEARCH OFTHE POLISH ACADEMY OF SCIENCES (WARSAW)

The New Humanities in Poland: A Few Very Subjective Observations, Supplements and Refutations

Nycz outlines the main trends in the New Humanities in the world - digital humanities, engaged humanities, cognitive humanities, posthumanism, art based research, as well as the main debates and misunderstandings that have emerged in the Polish context over the last decade. The evolution of ways of thinking and research is exemplified in literary-cultural studies, CTL. This acronym stands for various notions from cultural theory of literature to cultural-textual literacy.

\section{Keywords}

New Humanities, digital humanities, engaged humanities, cognitive humanities, posthumanism, art based research, CTL, cultural theory of literature, cultural-textual literacy 